\title{
Sobre o Uso de Princípios Teleológicos Na Filosofia, De Kant
}

\author{
Marcio Pires ${ }^{l}$
}

\section{INTRODUÇÁO}

A pequena dissertação Sobre o uso de princípios teleológicos na filosofia apareceu no Teutsche Merkur de janeiro-fevereiro de 1788. A circunstância da publicação é o debate entre Kant e Forster, a propósito das raças humanas². Kant responde aqui à objeçáo que Forster endereça a outros dois textos seus. A propósito de um ponto de relevância metodológica central, Forster ataca o procedimento de Kant, qualificando-o como alinhado à filosofia especulativa e abstrata $^{3}$, a qual, uma vez partindo de definiçóes, poderia incorrer no equívoco da parcialidade no tratamento das questôes e, consequentemente,

${ }^{1}$ Doutorando em Filosofia pela Universidade de São Paulo. Professor assistente (temporário) do Departamento de Filosofia da Universidade Estadual de Maringá. E-mail: mpcpires@yahoo.com.br.

${ }^{2}$ Johann Georg Adam Forster (27 de novembro de 1754 a 10 de janeiro de 1794). Naturalista alemão, Forster escreveu no Teutsche Merkur, de outubro e novembro de 1786, Noch etwas über die Menschenraßen (Algo mais sobre as raças humanas), texto no qual ele se refere a outros dois escritos de Kant: Bestimmung des Begriffs einer Menschenraße (Determinação do conceito de uma raça humana) e Muthmaßlicher Anfang der Menschengeschichte (Começo conjectural da história humana), ambos publicados na Berlinische Monatschrift, de 1785 e 1786, respectivamente.

3 'Definições (Bestimmungen) que se fundam sobre um conhecimento limitado podem ser úteis no interior desses limites, mas, tão logo se estenda o horizonte, desloque-se o ponto de vista, não parecerão elas semiverdadeiras e parciais?" (FORSTER, G. Noch etwas über die Menschenraßen. Teutsche Merkur. $4^{\circ}$ Trimestre, 1786, p. 61). Um pouco mais adiante, Forster se refere da seguinte maneira a um trecho do texto kantiano de 1785: "Se portanto o princípio (Satz) 'de que só se encontra na experiência o que se precisa, quando se sabe previamente pelo que procurar' (Berl. Monatsschrift, Novemb. 1785, p. 390), também tivesse sua exatidão incontestada, então também seria necessária um certa precaução no emprego do mesmo, para evitar a mais comum de todas as ilusôes, a saber, que em determinada busca por aquilo de que se precisa crê-se frequentemente encontrá-lo ali onde na verdade ele não está. Quanta calamidade nẫo surgiu desde sempre no mundo porque se partiu de definiçôes (Definitionen) das quais não se desconfiava, logo, inadvertidamente, alguém via por antecedência num certo clarão e enganava a si e aos outros" (Ibid., p.61-62). A digitalização do texto de Forster pode ser encontrada em: http://www.ub.uni-bielefeld.de/diglib/aufkl/teutmerk/ Acesso em: 30 jan. 2013. 
ignorar aquilo para o que as então recentes navegaçóes e os relatos de viagens haviam chamado atenção: a notícia da variada constituição física e cultural dos homens espalhados pela terra. Alguma dificuldade terminológica a propósito de termos como gênero, espécie etc. é referida pelo próprio Kant, mas, o que mais lhe parece importar será antes um esclarecimento em torno da questão do método que o naturalista deverá empregar nesse tipo de investigação. Forster receia partir do princípio; Kant, por sua vez, do dado bruto. Nesse ponto, a insistência kantiana será em torno de uma distinção necessária entre descrição da natureza (Naturbeschreibung) e história da natureza (Naturgeschichte).

A Crítica da razão pura, na Analitica Transcendental, foi capaz de fornecer um conjunto de regras gerais pelas quais uma "natureza em geral" podia ser pensada e especificada em juízos capazes de garantir um conhecimento objetivo. No entanto, o quadro de uma "objetividade em geral", não sendo capaz de satisfazer a razão em sua busca natural pela totalidade, termina por denunciar a característica essencialmente parcial de todo conhecimento objetivo. $\mathrm{O}$ caso é que, uma vez pressuposta a dimensão infinita do espaço e do tempo em que se circunscrevem os fenômenos, nenhum critério de decisão pode surgir para assegurar um ponto de interrupção da investigação e permitir afirmar que o todo foi passado em revista. Para além disso, há fenômenos naturais que se mostram tấo complexos e táo ordenados em vista de certas finalidades, a ponto de tornarem evidente a dificuldade de explicá-los meramente a partir de leis físico-matemáticas. É o caso em que a estrutura de uma "natureza em geral" se defronta com a vida ${ }^{4}$. Com isso, a possibilidade de explicar a totalidade por

\footnotetext{
${ }^{4}$ Nos Anfangsgründe, ao tratar da mecânica, Kant estabelece o limite em que deve mover-se uma filosofia da natureza como sendo o próprio lugar da ausência de vida. Esta última tem um princípio interno de ação e a matéria, somente um princípio externo, logo, na matéria, toda mudança tem causa externa, o que funda a lei da inércia: "A inércia da matéria é e nada mais significa do que sua ausência de vida enquanto matéria em si mesma. A vida é a capacidade (Vermögen) de uma substância de se determinar à ação por um princípio interno, de uma substância finita se determinar à mudança, de uma substância material se determinar ao movimento ou repouso como mudança de seu estado. Ora, nós não conhecemos nenhum outro princípio interno de uma substância para modificar seu estado que não seja a apetiçáo e, em geral, nenhuma outra atividade interna que não seja o pensar, com o sentimento de prazer ou desprazer e desejo ou vontade que dele dependem (...). $\mathrm{Na}$ lei da inércia (a par da permanência da substância) repousa inteiramente a possibilidade de uma genuína ciência da natureza. O contrário da primeira e daí a morte de toda filosofia da natureza seria o hilozoísmo." (MAN AA 04: 544). As citaçôes de Kant são feitas a partir da Akademie-Ausgabe, (Kants gesammelte Schriften/herausgegeben von der Königlich Preussischen Akademie der Wissenschaften), que será referida pela abreviaçáo (AA), antecedida das iniciais do título e seguida da indicaçáo do volume e da página, conforme o padrão definido pela Kant-Forschungsstelle (http://www.kant.uni.mainz.de/ks/ abhandlungen.html).
} 
meio de tal estrutura encontra um limite, o que já significa o surgimento de uma dificuldade para as exigências sistemáticas da razão.

A questão do sistema é frequente na filosofia de Kant. Ela se inscreve no interior das reflexôes kantianas sobre o método. A unidade sistemática, afirma o filósofo já no primeiro parágrafo da Arquitetônica da razão pura, "[...] é aquilo que primeiramente faz do conhecimento comum uma ciência" (KrV. A832/B860). Essa designação geral é, poucas linhas adiante, exemplificada pela referência ao organismo e seu desenvolvimento imanente em vista de fins essenciais. Em que pese não ser essa a única forma de sistema que a crítica expressa, ela parece ao menos ser a sua metáfora mais forte. Por outro lado, muito cedo, em 1755, Kant já tentava vincular as noçôes de sistema e desenvolvimento no âmbito da cosmologia. A sua História geral da natureza (Allgemeine Naturgeschichte und Theorie des Himmels) esforçava-se por não se resumir a uma descrição localizada e parcial dos fenômenos físicos. A intenção do filósofo ali, uma vez assumidas as leis fundamentais da matéria, foi elaborar uma teoria que pudesse fornecer uma explicação da gênese e constituição de um sistema do mundo 5 . Nesse texto, embora Kant assuma os princípios da física de Newton, ele segue adiante onde este último estaciona ${ }^{6}$. Para Kant, tratava-se sempre de, na maior extensão possível, explicar a natureza por si mesma, por suas leis internas, tanto quanto o princípio assumido o permitisse.

O texto "Sobre o uso de princípios teleológicos na filosofia" é, em boa medida, a explicitação de um modo de investigar pelo qual a constituição de um estado de coisas é, por assim dizer, explicitada em seu movimento genético. Aqui, não obstante o objeto já não ser a natureza em sua constituição físicomecânica, também se dá o caso de ir além da anotação superficial e meramente classificatória que uma descrição da natureza (Naturbeschreibung) poderia fornecer.

\footnotetext{
${ }^{5}$ Esse caráter, por assim dizer, genético ilumina o sentido pelo qual se qualifica uma teoria. Apenas descrever um estado atual das coisas, não resulta numa teoria consequente. Inscrever os fenômenos numa totalidade natural, já era para Kant, desde 1755, uma exigência metodológica. "Assim como entre todas as tarefas da investigação da natureza nenhuma pode ser resolvida com mais correçáo e certeza do que a da verdadeira constituição do edifício do mundo em geral, as leis dos movimentos e a mecânica interna das revoluçóes de todos os planetas, até onde a filosofia newtoniana pode garantir perspectivas tais que, aliás, não se encontram em nenhuma parte da filosofia; assim, afirmo que entre todas as coisas da natureza, por cuja primeira causa se procura, a origem do sistema do mundo e a produçáo dos corpos celestes com as causas de seus movimentos, são aquilo que primeiramente se pode esperar esmerada e seguramente compreender." (NTH AA 01: 229).

${ }^{6}$ Newton não explica o plano das órbitas dos planetas através de leis mecânicas, tendo assim que remetêlas ao "[...] domínio de um ser inteligente e poderoso" (NEWTON, I. Princípios matemáticos da filosofia natural. Trad. Carlos L. de Mattos e Pablo R. Mariconda. São Paulo: Abril Cultural, 1974, p. 26).
} 
$\mathrm{O}$ argumento assenta, sobretudo, na tentativa de construir uma história da natureza (Naturgeschichte). Já não se tratando de um recurso a princípios físicomatemáticos, é um princípio teleológico que, na insuficiência daqueles, deverá orientar a investigação para ordenar, unificar e explicar a diversidade que se oferece empiricamente. Esta é a tarefa da razão. Já prevenido pela Crítica, o texto de 1788 não afirma o caráter objetivo dos resultados de semelhante empreitada, como, decerto, seria o caso do texto de 1755 , no qual Kant, ao pensar uma totalidade do mundo físico, precipitava-se inevitavelmente no dogmatismo ainda por ser criticado. Todavia, tal como a tentativa daquele texto pré-crítico de aventar uma hipótese que explique desde o momento inicial como o edifício cósmico teria se ordenado e estruturado, em 1788, o fio condutor da teleologia é assumido como critério para arranjar uma variedade de fenômenos que, por si somente, a nada mais poderia prestar-se do que à descrição superficial ou, nas palavras de Kant, só permitiriam ao naturalista um "[...] mero andar às apalpadelas pelo empírico" (ÜGTP AA 08: 161). Uma história da natureza, diferente de uma classificação e divisão de seus produtos pelas simples características atualmente visíveis, deve forjar a hipótese do seu desenvolvimento e conjecturar a respeito das condiçóes a partir das quais o presente estado das coisas pode existir, não obstante o estatuto epistêmico mais frágil da empreitada ${ }^{7}$.

Assim como vários outros pequenos textos de Kant, escritos de circunstância, redigidos à margem da elaboração da trilogia crítica, este texto também se expressa em tom algo mais didático, ao menos se comparado à letra frequentemente árida com que o filósofo compôs as três Críticas. Para lá, contudo, da questão do estilo, também como em outros pequenos textos, é possível encontrar aqui esclarecimento a respeito de um tema com o qual a filosofia transcendental, na história de seu movimento constitutivo, deparouse e absorveu, obviamente, a seu modo próprio de tratamento, isto é, no intuito de descortinar-lhe a condição de possibilidade. Nesse caso, trata-se, é claro, do rearranjo que, logo depois, a Crítica da faculdade do juizo forneceria à teleologia, inscrevendo-a no quadro geral da filosofia transcendental sob a rubrica da conformidade a fins (Zweckmäßigkeit) enquanto um princípio próprio do juízo reflexionante. Isso, contudo, não diminui o valor do texto de 1788. Ele certamente mantém, ao menos, o caráter elucidativo do exemplo, ou seja, ele permite esclarecer como em uma investigação da natureza a assunção de um princípio teleológico pode e deve nortear a consideração dos fenômenos

\footnotetext{
${ }^{7}$ Em alguma medida, isso pode ser comparado com o que se afirma logo no início do texto de 1786, o "Começo conjectural". Trata-se, diz Kant, de algo que se anuncia "[...] apenas como um exercício permitido à imaginação em companhia da razão para o recreio e saúde do ânimo”. (MAM AA 08: 109).
} 
em vista da elaboração de uma teoria abrangente, no caso em questão, uma teoria antropológica que pudesse explicar a variada constituição humana catalogada pela observação, sem por isso ter que fender a humanidade em espécies diferentes. Por aí, o texto do filósofo faz entrecruzarem-se antropologia e biologia ${ }^{8}$ ou, mais precisamente, antropologia e embriologia, na medida em que a base de sustentação do argumento kantiano é a derivação das diferenças a partir de um estofo originário de germes e disposiçóes originárias que, uma vez pressupostos num tronco comum da humanidade, poderiam vir à tona conforme a ocasiáo o exigisse, a fim de fornecer à espécie certas qualidades úteis para contextos e necessidades específicas da vida.

Por fim, a despeito de não ter sido nomeada, embora indiretamente referida, há aqui um exemplo de como Kant realiza uma aplicação da teoria da epigênese, da ideia de uma pré-formação genérica, importante não só para sua concepçáo do organismo, mas também, mutatis mutandis, para a explicação da “[...] necessária concordância da experiência com os conceitos dos seus objetos [...]", tal como o testemunha a segunda edição da dedução transcendental da primeira crítica, ao afirmar um sistema da epigênese da razão pura ( $\mathrm{KrV}$ B 166) ${ }^{9}$.

\section{SOBRE O USO DE PRINCÍPIOS TELEOLÓGICOS NA FILOSOFIA ${ }^{10}$}

Se por natureza se entende o conjunto de tudo o que existe de modo determinado segundo leis, tomado o mundo (enquanto propriamente assim chamado natureza) juntamente com sua causa suprema, então se pode

\footnotetext{
${ }^{8}$ Quanto a essa aproximação, veja-se: COHEN, Alix A. Kant on epigenesis, monogenesis and human nature: the biological premises of anthropology. Stud. Hist. Phil. Biol. \& Biomed. Sci. 37, p. 675-693, (2006).

${ }^{9}$ Para uma introdução ao debate sobre a epigênese e sua relação com o tema da dedução das categorias, refiro, entre outros, os seguintes artigos: GENOVA, A. C. Kant's epigenesis of pure reason. KantStudien. Berlin, n. 65, p. 259-273, 1974; SLOAN, Phillip R. Preforming the categories: eighteenthcentury generation theory and the biological roots of Kant's a priori. Journal of the History of Philosophy. Vol. 40, n.2, p. 229-253, 2002; MARQUES, Ubirajara R. de Azevedo. Kant e a epigênese a propósito do 'inato'. Scientiae Studia. São Paulo, v.5, n.4, p. 453-470, 2007.

${ }^{10}$ Introdução, tradução e notas de Marcio Pires. Revisão: Clélia Aparecida Martins. A digitalização do texto pode ser acessada em http://www.ub.uni-bielefeld.de/diglib/aufkl/teutmerk/teutmerk. htm. A presente tradução foi feita a partir do texto da Akademie-Ausgabe (Kant's gesammelte Schriften/ Herausgegeben von der Königlich Preussischen Akademie der Wissenschaften); a paginação do texto no original consta em colchetes no corpo do texto. As notas do próprio Kant serão seguidas por $(\mathrm{K})$, as do tradutor, por (N.T.). Para esta traduçấo, foi útil ainda o cotejo com a versão francesa de Stéphane Piobetta, contida em: KANT. La philosophie de l'histoire: opuscules. Paris: Éditions Denoël, 1947, e com a versão inglesa de Günter Zöller, contida em: KANT. Anthropology, history and education. New York: Cambridge University Press, 2007.
} 
tentar a investigação da natureza por dois caminhos (que, no primeiro caso, se denomina física e, no segundo, metafísica), ou pelo caminho meramente teórico ou pelo caminho teleológico, pelo último caminho, porém, enquanto física, apenas empregando fins tais que nos possam ser conhecidos pela experiência, enquanto metafísica, ao contrário, de acordo com seu ofício, apenas empregando um fim estabelecido pela razão pura para seu propósito. Mostrei algures que na metafísica a razão não pode, a seu bel-prazer, alcançar toda sua intenção pela via teórica da natureza (em vista do conhecimento de Deus) e que, portanto, lhe resta tâo somente a via teleológica; de maneira que, não os fins da natureza, os quais assentam apenas em argumentos da experiência, mas um fim dado a priori de modo determinado pela razão pura prática (na ideia do Sumo Bem) deve completar o que falta à teoria insuficiente. Semelhante autorização e até mesmo necessidade de partirmos de um princípio teleológico ali onde a teoria nos abandona, eu busquei provar num pequeno ensaio sobre as raças humanas. Os dois casos, porém, contêm uma reivindicação à qual o entendimento se submete a contragosto e que pode dar suficiente pretexto a mal-entendidos.

Em toda investigação da natureza a razão apela, com direito, primeiramente à teoria e, só depois, à determinação do fim. Nem a teleologia, nem a conformidade a fim prática pode reparar a falta da primeira. Ainda que possamos tornar assim tão manifesta a exatidão de nossa pressuposiçấo a causas finais, sejam elas da natureza ou de nossa vontade, nós permanecemos sempre ignorantes relativamente às causas atuantes. Antes de tudo, essa demanda parece estar fundada lá onde (como naquele caso metafísico) devem mesmo preceder leis práticas para, primeiramente, indicar o fim em função do qual pretendo estipular o conceito de uma causa, o qual, de tal modo, em absolutamente nada diz respeito à natureza do objeto, parece [160], porém, ser simplesmente uma ocupação com nossas próprias intençôes e necessidades.

É sempre difícil chegar a acordo sobre princípios nos casos em que a razão tem um interesse duplo que se limita reciprocamente. Mas, inclusive, é difícil entender-se sobre princípios desse tipo, pois eles dizem respeito ao método de pensar antes da determinação do objeto, e as pretensôes da razão, conflitantes entre si, tornam ambíguo o ponto de vista a partir do qual se tem que considerar seu objeto. Na presente revista, dois ensaios meus, sobre dois assuntos muito diferentes e de relevância muito desigual, foram submetidos a um exame aguçado. Em um, eu não fui compreendido, embora esperasse sêlo; no outro, porém, fui bem compreendido para além de toda expectativa; 
em ambos os casos, por homens de talento excelente, vigor juvenil e próspera fama. No primeiro, caí na suspeita de querer responder a uma pergunta da investigação física da natureza através de documentos da religião; no outro, livrei-me da suspeita de prejudicar a religião, pela prova da insuficiência de uma investigação metafísica da natureza. Em ambos, a dificuldade de ser compreendido funda-se sobre a autorização, ainda não suficientemente posta às claras, de poder valer-se do princípio teleológico onde as fontes do conhecimento teórico não são suficientes, embora com uma limitação tal de seu uso que é assegurado o direito de precedência à investigação teóricoespeculativa, para primeiramente experimentar nisso toda a sua capacidade (pelo que, nas investigaçôes metafísicas, é, com direito, exigido da razão pura que ela justifique previamente isso e sua pretensão em geral de decidir sobre qualquer coisa e, ao mesmo tempo, porém, descubra completamente a condição de sua capacidade para que se possa lhe imputar confiança) e que, igualmente, essa liberdade sempre lhe permaneça assegurada. Uma grande parte da divergência assenta aqui sobre o receio da ruína com a qual a liberdade do uso da razão fica ameaçada; se isso for suprimido, então, creio poder remover facilmente os obstáculos à unanimidade.

Contra uma explanação da minha opinião expressa há muito tempo e inserida na Berl. M. S. de novembro de 1785, sobre o conceito e a origem das raças humanas, o conselheiro privado, Sr. Georg Forster, expôs, no Teutschen Merkur de outubro e novembro de 1786, objeçóes [161] que, como me parece, resultam simplesmente da incompreensão do princípio do qual parto. Na verdade, esse homem ilustre acha precário desde o início estipular previamente um princípio pelo qual o investigador da natureza deva deixarse conduzir, inclusive, nas pesquisas e observaçóes e, principalmente, por um princípio tal, que dirija a observação a uma história da natureza que por aí se promove, em contraste com a simples descriçâo da natureza; assim como essa própria diferenciação ele acha inadmissível. No entanto, essa divergência é facilmente superada.

A respeito da primeira dificuldade, é indubitavelmente certo que com o mero andar às apalpadelas pelo empírico, sem um princípio condutor segundo o qual se tem que investigar, nada conforme a fins jamais seria encontrado; pois, dispor a experiência metodicamente significa apenas observar. Agradeço ao viajante meramente empírico e a seu relato, especialmente quando tem a ver com um conhecimento coeso, do qual a razão pode fazer algo em proveito de uma teoria. Usualmente, depois de questionado, ele responde: eu bem poderia 
ter reparado nisso, se soubesse que me perguntariam depois. O próprio Sr. F, apesar disso, segue a orientação do princípio de Lineu da constância do caráter dos componentes da fecundação nas plantas, sem o qual a descrição sistemática da natureza do reino vegetal não teria sido ordenada e ampliada de modo tão notável. Infelizmente, é bem verdade que alguns sejam tão imprudentes a ponto de levar suas ideias para dentro da própria observação (e como sucedeu também ao grande conhecedor da natureza, de tomar a semelhança daquelas características, segundo certos exemplos, como uma indicação da semelhança das forças das plantas) e infelizmente é bem fundada a lição para pensadores apressados (o que presumivelmente em nada nos diz respeito); contudo, esse abuso náo pode revogar a validade da regra.

Mas, no que concerne à diferença posta em dúvida, pura e simplesmente rejeitada, entre descrição da natureza e história da natureza, se sob a última se quis entender um relato dos eventos naturais até onde nenhuma razão humana alcança, por exemplo, a primeira origem das plantas e animais, tal coisa evidentemente seria, como diz o $S$ r. F., uma ciência para deuses que estivessem presentes à criação ou mesmo que fossem autores, e não para os homens. Todavia, apenas perseguir regressivamente a conexão de certas qualidades atuais das coisas da natureza com suas causas em época remota, que nós não inventamos, mas [162] deduzimos das forças da natureza tal como elas agora se apresentam a nós, meramente recuar tão longe quanto no-lo permite a analogia, seria isso uma história da natureza e, na verdade, uma tal que não só é possível, mas também, por exemplo, nas teorias da terra de naturalistas metódicos (entre as quais a do famoso Lineu também encontra seu lugar) foram frequente e suficientemente tentadas, quer tenham elas alcançado muito ou pouco com isso. Também a própria conjectura do $S$ r. F. sobre a primeira origem dos negros não pertence à descrição da natureza, mas apenas à história da natureza. Essa diferença está posta na natureza das coisas, e através disso eu não reclamo nada de novo, mas simplesmente a cuidadosa separaçáo de uma coisa da outra, pois elas são completamente heterogêneas e, se aquela (a descrição da natureza), em toda suntuosidade de um grande sistema, aparece como ciência, a outra (a história da natureza) apenas pode indicar fragmentos ou hipóteses vacilantes. Através dessa separação e apresentação da segunda como uma ciência própria realizável, ainda que até agora (talvez também para sempre) mais como esboço do que como obra (ciência na qual para a maioria das questôes se poderia encontrar marcado 
um $\operatorname{Vacat}^{11}$ ), eu espero conseguir que não se faça, com pretenso conhecimento, em proveito de uma ciência algo que, na verdade, pertence táo somente à outra, e chegar a conhecer mais seguramente a extensão dos conhecimentos reais na história da natureza (pois se possuem alguns da mesma), ao mesmo tempo, também os limites da mesma que se encontram na própria razão juntamente com os princípios, segundo os quais ela se ampliaria da melhor maneira possível. Há que se considerar bem esse escrúpulo, já que anunciei ter experimentado noutros casos tanta calamidade por causa da negligência de soltar entre si os limites das ciências e não ter agradado precisamente a todos; além do mais, com isso eu fiquei inteiramente convencido de que, pela simples separação do dissemelhante que antes se havia tomado num agregado, abre-se frequentemente uma luz inteiramente nova para as ciências, com a qual, na verdade, se descobre muita mesquinhez, que antes se pôde esconder por detrás de conhecimentos estranhos, mas igualmente se abrem ao conhecimento muitas fontes autênticas onde absolutamente náo se poderia ter presumido. A maior dificuldade nessa pretensa inovação está apenas no nome. A palavra história, visto que exprime o mesmo que a grega Historia (relato, descrição) já está muito usada e há muito tempo, para que se deva facilmente consentir [163] competir-lhe uma outra significação que possa designar a investigação natural da origem; uma vez que nesta última também não se está isento de dificuldade para descobrir uma outra expressão técnica que lhe seja ajustável ${ }^{12}$. Todavia, a dificuldade da língua em discernir não pode suprimir a diferença das coisas. Presumivelmente, precisamente a mesma divergência por causa de um afastamento conquanto inevitável das expressóes clássicas, também no caso do conceito de raça, tem sido a causa da desunião sobre a mesma coisa. Ocorreu-nos aqui o que Sterne disse por ocasião de um debate sobre fisionomia que, segundo suas ideias caprichosas, pôs em alvoroço todas as faculdades da Universidade de Estrasburgo: os lógicos teriam decidido o assunto, não tivessem eles apenas se deparado com uma definição. O que é uma raça? A palavra absolutamente não figura em um sistema de descriçáo da natureza, presumivelmente, portanto, também a própria coisa não está na natureza. $\mathrm{O}$

\footnotetext{
${ }^{11}$ Vacat, de acordo com o dicionário latino-português de Saraiva, designa o "estar vazio", "vago", "desocupado" (SARAIVA, F. R. dos Santos. Novíssimo dicionário latino-português: etimológico, prosódico, histórico, geográfico, mitológico, biográfico, etc. Rio de Janeiro: Garnier, 2006). Sigo aqui a nota explicativa da já referida tradução inglesa de Günter Zöller, a propósito da expressão acima: "Latim para 'ficar vazio', indicando uma falta de resposta". (On the use of teleological principles in philosophy. Translated by Günter Zöller. In: Immanuel Kant: Anthropology, History and Education. New York: Cambridge University Press, 2007, p. 198). (N.T.)

${ }^{12}$ Eu proporia para a descrição da natureza a palavra Fisiografia, para a história da natureza, porém, Fisiogonia. (K)
} 
conceito que essa expressão designa é, porém, muito bem fundado na razão de cada observador da natureza, o qual, para uma característica herdada de animais diferentes que se procriam por cruzamento, a qual não está no conceito de sua espécie, faz a ideia de uma comunidade da causa e, na verdade, de uma causa originalmente posta no tronco da própria espécie. Que essa palavra não ocorra na descrição da natureza (mas que em seu lugar se encontre a palavra variedade) não pode impedi-lo de julgá-la necessária em vista da história da natureza. Ele, decerto, apenas deve defini-la claramente em função disso; e isso nós desejamos tentar aqui.

O nome de uma raça, enquanto característica radical que dá informação sobre a origem em uma linhagem comum e, ao mesmo tempo, admite vários caracteres que persistem passando à posteridade náo somente da mesma espécie animal, mas também do mesmo tronco, não é concebido de modo impróprio. Eu o traduziria por derivação (progenies classifica), para diferenciar uma raça da degeneração (degeneratio s. progenies specifica) ${ }^{13}$ [164], a qual não se pode conceder, pois contraria a lei da natureza (na conservaçáo de suas espécies em forma constante). A palavra progenies indica que não são caracteres originais distribuídos por tantos troncos quanto espécies do mesmo gênero, mas, caracteres que primeiramente se desenvolvem na série das geraçôes, por conseguinte, não são tipos diferentes mas, derivaçôes, todavia, tão definidas e persistentes que autorizam uma distinção de classes.

De acordo com esses conceitos prévios, a espécie humana (tomada segundo o traço característico da mesma na descrição da natureza) poderia, em um sistema da história da natureza, ser dividida em tronco (ou troncos), raças ou derivaçóes (progenies classificae) e diferentes tipos humanos (varietates nativae), esses últimos não contendo traços característicos perduráveis que se transmitam segundo uma lei indicada, portanto, seriam também insuficientes para uma divisão de classe. Tudo isso, porém, é uma simples ideia do modo como a maior multiplicidade na geração é unificada pela razão com a maior unidade da origem em uma linhagem. Se efetivamente há um tal parentesco

${ }^{13}$ As designaçóes classes e ordines exprimem de modo inteiramente inequívoco uma abstração meramente lógica, que a razão faz entre seus conceitos em proveito da simples comparação: mas genera e species podem significar também a separação física que a própria natureza faz entre suas criaturas relativamente à sua produção. $\mathrm{O}$ caractere da raça pode, portanto, bastar para, [164] segundo isso, classificar criaturas, mas não para tirar daí uma espécie particular, pois essa poderia também significar uma descendência particular que nós não pretendemos que seja entendida sob o nome de uma raça. É claro que nós não tomamos aqui a palavra "classe" no significado amplo, tal como é tomada no sistema de Lineu; mas nós a utilizamos também para a divisăo com um propósito inteiramente diferente. (K). 
na espécie humana, as observaçốes que dão a notar a unidade da descendência devem decidir. Aqui se vê claramente que se deve ser guiado por um princípio determinado para simplesmente observar, isto é, atentar para aquilo que indica a linhagem original e não só os caracteres semelhantes; porque temos a ver com uma tarefa da história da natureza e não com a descrição da natureza e uma nomenclação meramente metódica. Alguém que não tenha disposto sua investigação de acordo com aquele princípio, deve novamente investigar, pois, por si mesmo, não se lhe apresenta aquilo que ele precisa para estipular se há um parentesco real ou apenas nominal entre as criaturas.

Não pode haver característica mais segura da diversidade do tronco original do que a impossibilidade de obter uma prole fértil pelo cruzamento de duas divisóes humanas hereditariamente dis- [165] tintas. Mas se esse cruzamento tem êxito, então, ainda assim a grande diferença da forma não obsta para, ao menos possivelmente, encontrar uma linhagem comum aos mesmos; pois, não obstante esta diferença, assim como eles puderam se unificar através da procriação em um produto que contém as características de ambos, eles, também pela procriação, poderiam se dividir em tantas raças a partir de um tronco que originalmente ocultava em si as disposiçóes para o desenvolvimento de ambas as características; e, sem necessidade, a razão não parte de dois princípios, quando ela pode contentar-se com um. Não obstante, o traço característico seguro das peculiaridades hereditárias, como os sinais distintivos de tantas raças, já foi mencionado. Agora, é de se observar ainda algo das variedades hereditárias que dão ocasiáo para a denominação de um ou outro tipo humano (tipos de famílias e de povo).

Uma variedade é a característica hereditária que não é classificável, porque não se reproduz infalivelmente; pois uma semelhante constância do caráter herdado é exigida, mesmo para a descrição da natureza, para justificar a divisão em classes. Uma forma que na reprodução só de vez em quando reproduz o caractere dos pais mais próximos e, precisamente na maior parte, apenas de um lado (seguindo o tipo do pai ou da mãe), não é um sinal distintivo pelo qual se pode conhecer a linhagem de origem dos dois pais; por exemplo, a diferença de loiros e morenos. Do mesmo modo, a raça, ou derivação, é uma peculiaridade hereditária perdurável que, na verdade, autoriza a divisão em classes, mas não é, todavia, específica, porque a reprodução miscigenada que perdura (portanto, a fusão dos caracteres de sua diferença), ao menos, não permite julgar como impossível considerar sua diferença também primitivamente em seu tronco, como unificadas em simples disposiçóes e 
apenas desenvolvidas e separadas gradualmente na reprodução. Pois não se pode fazer de um gênero animal uma espécie particular, se ele pertence com outro a um mesmo sistema de procriação da natureza. Por conseguinte, na história da natureza, gênero e espécie ${ }^{14}$ significariam o mesmo, a saber, a característica herdada que náo é partilhada com uma linhagem comum de origem. Porém, a característica hereditária que pode coexistir com isso é necessariamente hereditária ou não. No primeiro caso, constitui o caráter da raça, no outro, o da variedade.

Daquilo que na espécie humana pode ser chamado variedade, eu observo aqui que também relativamente a esta não se tem que considerar a natureza [166] como formadora em completa liberdade, mas, assim como no caso dos caracteres das raças, apenas como desenvolvendo predeterminadamente a mesma, através de disposiçóes originais: porque, na variedade, encontra-se igualmente uma conformidade a fins e uma medida conveniente à mesma, que não pode ser obra do acaso. O que já notou Lord Shaftsbury, a saber, que em cada face humana se encontra uma certa originalidade (por assim dizer, um design efetivo) que definitivamente distingue o indivíduo por fins específicos que ele não tem em comum com outros e, embora decifrar esses traços ultrapasse nossa capacidade, isso todo retratista que pensa sobre sua arte pode confirmar. Em uma imagem pintada e bem expressa sobre a vida vê-se a verdade, ou seja, que ela não é tirada da imaginação. Entretanto, em que consiste essa verdade? Sem dúvida, para, em uma determinada proporção de uma das várias partes da face com todas as outras, exprimir um caráter individual que contém um fim obscuramente representado. Nenhuma parte da face, ainda que nos pareça desproporcional, pode, conservando-se as demais, ser mudada no retrato, sem que imediatamente se torne perceptível ao olho de um perito, ainda que ele não tenha visto o original, ao comparar com aquele retrato copiado da natureza, qual de ambos contém a pura natureza e qual a invenção. Conforme toda probabilidade, a variedade entre homens da mesma raça foi posta no tronco original de maneira tão adequada à maior multiplicidade, em proveito de fins infinitamente diversos, assim como a diferença de raças o foi para fundar e, na sequência, desenvolver a aptidão a menos fins, porém, mais essenciais; com o que, portanto, reina a diferença, pois as últimas disposiçóes, após terem se desenvolvido uma vez (o que já deve ter sucedido em tempo mais remoto) não deixam nascer novas formas desse tipo, nem as velhas se extinguirem; ao contrário, as primeiras disposiçóes, ao menos segundo nosso conhecimento,

${ }^{14}$ No original: Gattung und Species (N.T.). 
parecem indicar uma natureza inexaurível em novos caracteres (tanto externos como internos).

Quanto às variedades, a natureza parece evitar a fusão, porque esta é contrária a seu fim, a saber, à multiplicidade de caracteres; ao contrário, no que concerne às diferenças de raças, ainda que não favoreça, ela ao menos permite a mesma (isto é, a fusáo), porque, através disso, a criatura torna-se apta a vários [167] climas, embora a nenhum deles em grau adequado, como o havia feito a primeira conformação aos mesmos. Quanto à opiniâo comum, segundo a qual as crianças (de nossa classe de brancos) devem herdar da parte de seus pais (como se diz: isso a criança tem do pai, isso ela tem da mãe) os traços característicos que pertencem à variedade (como estatura, a forma do rosto, a cor da pele, mesmo alguns defeitos tanto internos como externos), náo posso aderir a tal opiniāo depois de atentar cuidadosamente ao tipo das famílias. As crianças, ainda que não do pai ou da mãe, seguem o tipo, sem mistura, ou da família de um ou de outro; e malgrado a repulsa às misturas de parentes muito próximos tenha em grande parte causas morais, mesmo a infertilidade delas não poderia ser suficientemente provada: assim, sua ampla difusão até mesmo entre os povos rudes dá ocasião à suspeita de que o fundamento para isso esteja posto de modo distante na própria natureza, a qual não quer que sempre sejam reproduzidas as velhas formas e sim que venha à tona toda multiplicidade que ela tinha posto no germe originário da espécie humana. Um certo grau de uniformidade, que se descobre num tipo de família ou até mesmo num povo, não pode ser atribuído à conformação miscigenada de seus caracteres (que na minha opinião, absolutamente, não encontra lugar quanto às variedades). Pois a preponderância da força de geração de uma ou outra parte das pessoas casadas, já que às vezes quase todas as crianças seguem ou a linhagem paterna ou a materna, pode - ao lado da grande diferença inicial de caracteres, pela ação e reação, isto é, por meio do que as reproduçóes do tipo de um lado se tornam sempre mais raras - diminuir a multiplicidade e produzir uma certa uniformidade (que só é visível a olhos estranhos). Isso, todavia, é apenas minha opinião casual, que deixo ao leitor para julgá-la a seu gosto. $\mathrm{O}$ mais importante é que nos outros animais quase tudo o que neles se poderia chamar variedade (como a estatura, o tipo de pele etc.) conforma-se parcialmente, e isso, quando se considera o homem, como convém, em analogia com os animais (a propósito da reprodução), parece conter uma objeção à minha diferenciação entre raças e variedades. Para julgar isso, é preciso já tomar um ponto de vista mais elevado para a explicação desse arranjo natural, a saber, que os animais desprovidos de razão, [168] cuja existência somente pode ter 
um valor como meio, deviam, por isso, já na disposição, serem distintamente dotados para diferentes usos (como as diversas raças de cães, que para Buffon são derivadas da linhagem comum do cão pastor); na espécie humana, ao contrário, a maior unanimidade do fim não reclamou tão grande diferença de formas naturais conformadas, que, necessariamente conformadas apenas para a conservação, poderiam ser postas em alguns poucos climas diferentes entre si. Contudo, já que eu apenas quis defender o conceito de raças, não tenho a necessidade de responder pelo fundamento de explicaçáo das variedades.

Após a dissolução desse desacordo linguístico, que frequentemente é mais culpado pela contenda do que aquele desacordo em princípios, eu espero agora encontrar menos obstáculo contra a afirmação de meu modo de explicação. Nisso o senhor $F$. está de acordo comigo, pois, entre as diferentes figuras humanas, a saber, a dos negros e dos demais homens, ele encontra ao menos uma propriedade hereditária suficientemente importante, para não tomá-las por um mero jogo da natureza e efeito de impressão casual, mas exige para isso disposiçóes originalmente incorporadas à linhagem e arranjo específico da natureza. Tal unanimidade de nossos conceitos já é importante e torna possível uma aproximação quanto aos princípios de explicação de ambos os lados; em vez do modo comum e superficial de representação que toma em pé de igualdade toda a diferença de nossa espécie, isto é, sob o acaso, e sempre ainda a deixa surgir e desaparecer como o dispóem as circunstâncias externas, declara superficial todas as investigaçóes desse tipo e, com isso, nula a própria constância da espécie na mesma forma adequada. Apenas duas diferenças entre nossos conceitos ainda permanecem, as quais não estão tão distantes entre si para necessariamente jamais tornar superável a divergência: a primeira é que as propriedades hereditárias aí cogitadas, a saber, aquelas dos negros em contraste com todos os outros homens, são as únicas que devem merecer ser tomadas por originalmente implantadas; nesse caso, eu julgo, ao contrário, que ainda várias outras também são autorizadas para uma divisão de classificação completa (a do indiano e americano, acrescidas àquela dos brancos): o segundo distanciamento, o qual porém não concerne tanto à observação (descrição da natureza) quanto à teoria a admitir (história da natureza), é que o Sr. F. acha necessário [169] dois troncos originais para esclarecer esses caracteres; ora, na minha opinião (que considero igual à do Sr. F. para os caracteres originais), é possível e, nesse caso, mais conforme ao modo de explicação filosófico, considerá-las como desenvolvimento de primeiras disposiçóes conformes a fins implantadas num tronco; o que, com efeito, também não é dissensão tấo grande que a razão a esse respeito não 
ofereça também a mão, se se considera que a primeira origem física do ser orgânico permanece insondável para nós dois, e em geral para a razão humana, bem como a conformação híbrida na reprodução deles. Já que o sistema dos germes desde o início separados e isolados em dois troncos - embora harmoniosamente de novo logo fundidos na mistura do até entâo segregado - não proporciona, em vista da compreensão pela razão, a menor facilidade mais do que aquele sistema dos germes diferentes, originalmente implantados em um e mesmo tronco, desenvolvendo-se, na sequência, em conformidade ao primeiro povoamento geral; e, nesse caso, a última hipótese comporta ainda a prerrogativa de poupar diversas criaçóes locais; já que, além disso, não é, absolutamente, de se pensar na economia dos princípios teleológicos de explicação para, nesse caso do ser organizado, naquilo que diz respeito à conservação de seu tipo, substituí-los pelos princípios físicos, e o último modo de explicação não impóe à investigação da natureza nenhuma nova carga além daquela, da qual, além disso, ela jamais pode estar isenta, a saber, de unicamente seguir aí o princípio dos fins; já que, também, o Sr. F., na verdade, somente através das descobertas de seu amigo, o famoso anatomista filosófico, Sr. Sömmering, foi levado a achar a diferença entre os negros e os outros homens mais relevante do que o poderia agradar àqueles que de bom grado confundem entre si todos os caracteres hereditários e gostariam de considerá-los meras matizações contingentes; e esse homem distinto qualifica ${ }^{15}$ a formação do negro, relativamente à sua terra natal, como uma perfeita conformidade a fins, apesar de que não é, todavia, precisamente observável na estrutura óssea da cabeça [170] uma adequação ao seu solo mais compreensível do que na organização da pele, esse grande instrumento de eliminação de tudo aquilo que deve ser purgado do sangue - por conseguinte, ele parece entender essa a partir de todo o distinto arranjo natural restante (do que a qualidade da pele é uma parte importante) e somente estabelece aquela como um sinal mais claro da mesma para o anatomista: quando provado que há ainda em menor número outras propriedades que se transmitem tão constantemente, que absolutamente não confluem entre si segundo as gradações do clima, mas são

\footnotetext{
15 Sömmering, Sobre a diferença corporal do negro e do europeu. p. 79. "Encontram-se na estrutura do negro propriedades que o tornam para seu clima a mais perfeita criatura, talvez, mais perfeita que o europeu". Esse homem distinto põe em dúvida (no mesmo escrito $\$ 44$ ) a opinião de D. Schott de que a pele do negro seria mais habilmente organizada para uma melhor eliminaçáo de matérias nocivas. Mas, quando se vinculam a isso as informaçôes de Lind (Das doenças dos europeus etc.) sobre a nocividade do ar [170] flogístico das florestas pantanosas nos arredores do rio Gâmbia, que tão rápido se torna mortal aos marinheiros ingleses, em meio ao qual, todavia, os negros vivem como que em seus elementos, entẫo aquela opiniâo ganha muita probabilidade. (K).
} 
nitidamente segmentadas, ainda que elas não caiam na especialidade da arte da anatomia, é de se esperar que o $S$ r. F. não será avesso a conceder-lhes uma igual pretensão a germes particulares originais, convenientemente implantados no tronco. Se, porém, é necessário admitir para isso vários ou apenas um tronco comum, é de se esperar que, quanto a isso, poderíamos ainda, por fim, nos colocarmos em acordo.

Assim, seria preciso apenas remover as dificuldades que impedem o Sr. F. de aderir à minha opiniáo, não tanto relativamente ao princípio, mas muito antes quanto à dificuldade de adaptá-lo convenientemente a todos os casos de aplicação. Na primeira seção de seu ensaio de outubro de 1786, p. 70, o Sr. F. faz uma escala de cores da pele desde os habitantes da Europa do norte, passando pela Espanha, Egito, Arábia, Abissínia até o equador, de lá, porém, novamente volta, em matização inversa com o afastamento pela zona temperada do sul, passando pelas terras dos cafres e hotentotes, com uma gradação do moreno até o negro e vice versa, (segundo sua opinião) táo proporcional ao clima das terras (com o que, ele admite, ainda que sem prova, que as colônias provindas dos negros que rumaram para o extremo da África se transformaram nos cafres e hotentotes simplesmente pelo efeito do clima) que the surpreendeu como ainda não se poderia ter feito caso disso. Mas, justamente deve surpreender ainda mais, como se poderia não fazer caso do traço característico conservado, suficientemente determinado e, com fundamento, o único decisivo para a procriação infalivelmente miscigenada, do que tudo depende aqui. [171] Pois, nem o europeu que está mais ao norte, no cruzamento com aqueles de sangue hispânico, nem o mauritano ou árabe (presumivelmente também o abissínio, que lhe é estreitamente aparentado) no cruzamento com as mulheres circassianas estão minimamente sujeitos a essa lei. Não há igualmente motivo para, depois de pôr de lado o que o sol de sua terra imprimiu a cada indivíduo, julgar sua cor como algo diferente dos morenos entre os tipos humanos brancos. Contudo, no que tange à semelhança dos cafres com os negros e, em menor grau, dos hotentotes na mesma parte do mundo, o que presumivelmente sustentaria a prova da geração mestiça, então, é muitíssimo provável que isso não poderia ser outra coisa do que procriaçóes bastardas de um povo negro com aqueles árabes, visitantes dessa costa desde muito tempo. Como, pois, não se encontra também a mesma suposta escala de cores na costa oeste da África, onde a natureza do árabe moreno ou mauritano dá um salto ainda mais repentino para os mais escuros negros no Senegal, sem antes ter passado pela via mediana dos cafres? Com isso, fica suprimida a tentativa de prova previamente decidida e aduzida na 
página 74, que deveria demonstrar a inadmissibilidade do meu princípio, a saber, que o abissínio moreno escuro cruzado com uma cafre não resultaria, segundo a cor, em nenhum tipo intermediário, porque ambas as cores são a mesma, isto é, o moreno escuro. Pois, já que o $S r$. $F$. admite que a cor morena do abissínio, na intensidade como a têm os cafres, lhe seja inata, e tal que, na verdade, na geração cruzada com uma branca deveria resultar necessariamente em uma cor intermediária: assim o ensaio resultaria tal como o quer o $\mathrm{Sr}$. $F$; ele, todavia, também nada provaria contra mim, porque náo se ajuíza a diferença das raças conforme aquilo que nelas é igual, mas de acordo com o que nelas é diferente. Apenas se poderia dizer que também há raças de um moreno intenso que se distinguem do negro ou de sua linhagem de origem $\mathrm{em}$ outros sinais distintivos (por exemplo, pela estrutura óssea); porque, apenas em vista destes a geração daria um bastardo e minha lista de cores só aumentaria em um. Porém, a cor intensa que o abissínio crescido em seu país ostenta não é herdada, mas apenas, mais ou menos como a de um espanhol que na mesma terra fosse educado desde pequeno: assim, sem dúvida, sua cor natural daria com aquela dos cafres um tipo mediano de geração, o qual, todavia, por conta da aparência contingente [172] acrescida pelo sol, seria escondido e (segundo a cor) pareceria ser um tipo idêntico. Portanto, esse ensaio projetado nada prova contra a aptidão da cor da pele necessariamente herdada para uma distinção das raças, mas apenas a dificuldade de poder determiná-la corretamente, na medida em que ela é inata, no lugar onde o sol a cobre ainda com uma maquiagem casual, e confirma a legitimidade da minha reivindicação de preferir, para esse fim, as geraçóes dos mesmos pais no estrangeiro.

Ora, das últimas nós temos um exemplo decisivo na cor da pele indiana de um pequeno povo que desde alguns séculos se reproduz em nossos países nórdicos, a saber, os ciganos. Que eles sejam um povo indiano prova sua língua, independentemente da cor de sua pele. Mas, para conservá-la, a natureza foi táo obstinada que, se com efeito se pode observar sua presença na Europa em até doze geraçôes atrás, ela ainda sempre aparece tão integralmente que, se eles crescessem na Índia não seria encontrada, segundo toda suposição, absolutamente nenhuma diferença entre eles e os nascidos lá naquele país. Agora, dizer aqui que ainda se deveria esperar 12 vezes 12 geraçóes até que o ar do norte tenha descorado completamente sua cor hereditária seria entreter o investigador com respostas dilatórias e buscar subterfúgios. No entanto, fazer sua cor passar por simples variedade, mais ou menos como a cor do espanhol moreno frente aos dinamarqueses, seria duvidar da impressão da natureza. Pois, com os nossos antigos nativos, eles geram infalivelmente crianças 
miscigenadas, lei à qual a raça dos brancos não está submetida relativamente a nenhuma de suas variedades características.

Não obstante, as páginas 155-156 apresentam o mais importante contra-argumento, pelo qual, caso ele fosse fundado, se demonstraria, ainda que se me concedesse as minhas disposiçóes originais, que a conveniência dos homens em suas terras natais junto de sua difusão pela superfície da terra não poderia subsistir com isso. Talvez, diz o $S r$. F., se possa ainda defender que precisamente aqueles homens, cuja disposição convém a este ou àquele clima, teriam nascido aqui e ali por um sábio arranjo da providência: mas como, continua ele, a mesma providência tornou-se tão míope para não pensar numa segunda transplantação onde aquele germe, que apenas servia para um clima, se tornaria completamente inútil?

[173] No que diz repeito ao primeiro ponto, há que se recordar que eu náo tinha admitido aquelas primeiras disposiçóes como repartidas entre vários homens - porque então resultariam em muitos troncos diferentes mas, como unidas no primeiro par humano; e assim, seus descendentes, nos quais a inteira disposição original para todas as futuras derivaçôes está ainda indivisa, conviriam a todos os climas (in potentia), isto é, tal que aquele germe que os tornaria adequados para aquele lugar da terra no qual eles ou seus primeiros descendentes chegariam poderia desenvolver-se. Portanto, não foi necessário nenhum particular arranjo sábio para levá-los a lugares tais que suas disposiçôes fossem adequadas; entretanto, onde quer que casualmente chegaram e sua geração continuou por muito tempo, ali se desenvolveu o germe existente em sua organização para essa região da terra e que os tornou adequados a semelhante clima. O desenvolvimento das disposiçóes orientouse de acordo com os lugares e náo os lugares, por acaso, tiveram que ser selecionados para as disposiçóes já desenvolvidas, como equivocadamente o entende o $S r$. F. Tudo isso alhures, só se compreende de um tempo remoto que deve ter durado o suficiente (para o povoamento gradual da terra) para, primeiramente, proporcionar a um povo, que tinha um lugar permanente, a influência do clima e do solo requerida para o desenvolvimento de suas disposiçôes adequadas aos mesmos. Mas agora, continua ele: como o mesmo Entendimento, que calculou aqui tão corretamente quais países e quais germes deviam coincidir (segundo o que precede, eles tinham que sempre coincidir, ainda que não se queira que um Entendimento, mas, que apenas a própria natureza, que arranjou internamente a organização dos animais assim tấo universalmente adequada, também os tenha equipado precisamente de 
modo tão cuidadoso para sua conservação), de repente tornou-se tão míope que também não previu o caso de uma segunda transplantação. Pelo que, a peculiaridade inata que serve somente para um clima se torna inteiramente inútil etc.

Agora, no que concerne ao segundo ponto da objeção, eu admito que aquele Entendimento, ou caso se preferir, aquela Natureza por si mesma convenientemente atuante segundo germes já desenvolvidos, de fato, não tenha, absolutamente, dado atenção à transplantação, sem que por isso, todavia, possa ser culpada de imprudência e miopia. Pelo contrário, pela sua adequação ajustada ao clima, ela impede a mudança do mesmo, especialmente do quente por frio. Pois, precisamente essa má acomodação do novo clima para a natureza já [174] conformada do habitante do clima antigo, o impede disso por si mesmo. E onde indianos e negros tentaram se espalhar nas regióes nórdicas? - Aqueles que, porém, para lá são expulsos (como os negros crioulos ou os indianos sob o nome de ciganos) jamais quiseram em sua descendência dar um tipo útil, para o cultivo domiciliado da terra ou para o trabalho manual ${ }^{16}$.

${ }^{16}$ Esta última nota não é mencionada aqui como prova, porém, também não é irrelevante. Nas Contribuiçôes do Sr. Sprengel, 5a Parte, p. 287-292, contra o desejo de Ramsay de usar todos os escravos negros como trabalhadores livres, um perito alega que, entre os milhares de negros livres que se encontram na América ou na Inglaterra, ele não conhece nenhum exemplo de qualquer um que se dedique a uma ocupação que, propriamente, se possa chamar trabalho, pelo contrário, quando chegam à liberdade, imediatamente renunciam a um ofício fácil, que antes foram forçados a exercer como escravos, para se tornarem mascates, estalajadeiros miseráveis, serviçais livres, que vão à pesca ou à caça, numa palavra, errantes. Igualmente isso ocorre entre nós com os ciganos. $\mathrm{O}$ mesmo autor observa nessa ocasião que não é o clima nórdico que os torna pouco inclinados ao trabalho, pois, quando atrás do carro de seus senhores ou quando, nas mais fortes noites de inverno, precisam esperar nas frias entradas do teatro (na Inglaterra), eles preferem resistir a ter que debulhar, cavar, levar cargas etc. Disso não se deveria concluir que, além da capacidade de trabalhar, ainda haja, imediata e independentemente de toda atração, uma inclinação para a atividade (especialmente a atividade persistente, que se chama assiduidade), a qual é particularmente entretecida com certas disposiçóes naturais e que, tanto indianos como negros, em outros climas, não tragam mais consigo e não transmitam mais desse impulso, tal como, em seu antigo país natal, eles precisavam para sua conservação e tinham recebido da natureza; e, tấo pouco, que se extinguiu essa disposição interna tanto quanto a visível externamente. As necessidades extremamente diminutas naqueles países e o pouco esforço que se exige para também garanti-las não demanda grandes disposiçóes para a atividade. Eu quero ainda mencionar aqui algo da cuidadosa descriçẫo de Sumatra de Marsden (Ver Sprengel, Contribuiçôes, 6a Parte, p. 198-199). "A cor de sua pele (dos Rejangs) é comumente amarela sem a mistura do vermelho, que produz a cor de cobre. Eles são, quase sem exceção, um tanto mais claros de cor do que os mestiços de outras regióes da Índia. A cor branca dos habitantes de Sumatra, em comparação com outros povos de clima semelhante, é, a meu ver, uma forte prova de que a cor da pele de modo algum depende imediatamente do clima. (Ele diz o mesmo das crianças de europeus e negros lá nascidas na segunda geração, e presume que a cor escura dos europeus que estáo aqui há tempos seja uma consequência das muitas doenças da bílis às quais todos estão expostos lá). Aqui devo ainda observar que as mãos [175] dos nativos e mestiços, apesar do clima quente, habitualmente sâo frias" (um fato importante que dá a informação de que a 
[175] Mas justamente isso que o Sr. F. mantinha, contra o meu princípio, como uma dificuldade insuperável, lança sobre a mesma, numa certa aplicação, a mais vantajosa luz e resolve as dificuldades contra as quais nenhuma outra teoria era capaz de algo. Eu admito que muitas geraçôes foram necessárias, desde o tempo do início da espécie humana, para a completa conformação a um clima, por um desenvolvimento gradual das disposiçóes nela existentes e que então a difusão da mesma sobre a parte mais considerável da terra, forçada na maioria da vezes por uma violenta revolução natural, poderia ter acontecido com uma escassa multiplicação da espécie. Se, pois, também por essas causas um pequeno povo do mundo antigo foi conduzido das regióes do sul para as nórdicas: assim, a conformação, que talvez ainda não estava inteiramente acabada para ser adequada às primeiras, teve que ser gradualmente suspensa para, em compensação, dar lugar a um desenvolvimento oposto das disposiçôes, isto é, para o clima nórdico. Agora, posto que esse tipo humano tivesse se deslocado sempre mais para nordeste até a América - uma opinião que, francamente, possui a maior probabilidade - então, antes que ele naquela parte do mundo pudesse de novo se espalhar consideravelmente para o sul, suas disposiçôes naturais estariam já tâo desenvolvidas quanto possível e aquele desenvolvimento, agora acabado, deveria ter tornado impossível toda ulterior conformação a um novo clima. Nesse ponto, surgiria uma raça que, em seu afastamento em direção ao sul permaneceria sempre a mesma para todos os climas, portanto, na verdade a nenhum convenientemente adequada, porque sua conformação ao sul, anterior à sua partida, foi interrompida no meio de seu desenvolvimento pela mudança para o clima nórdico e produziu então uma condição constante para essa população. Na verdade, Dom Ulloa (uma excelente e importante testemunha, que conheceu os habitantes das Américas nos dois hemisférios) assegura ter achado as feições características dos habitantes dessa parte do mundo, em geral, muito semelhantes (no que diz respeito à cor, um dos novos navegadores, cujo nome agora eu náo posso dar com segurança, a descreve como a ferrugem misturada com óleo). Mas, que a sua índole natural não alcançou nenhuma adequação completa a um clima qualquer, disso deixa-se também deduzir que dificilmente [176] pode ser indicada uma outra causa pela qual essa raça, tão frágil para o trabalho pesado, tão indiferente ao assíduo, e incapaz de toda cultura (para o que,

índole característica da pele não deve advir de causas externas superficiais). (K). Embora o etnônimo "Rejangue" tenha ocorrência registrada e expresse um aportuguesamento possível, preferimos manter a escrita original de Kant, já que náo encontramos a grafia, acima citada, formalmente expressa em dicionário. (N.T.). 
todavia, encontra-se na proximidade exemplo e encorajamento suficientes) está ainda muito abaixo do próprio negro, o qual, contudo, ocupa o mais baixo de todos os demais níveis daquilo que nós nomeamos diferença de raças.

Agora, que se considere todas as outras hipóteses possíveis quanto a este fenômeno! Se não se quer acrescentar à criação particular do negro, já proposta pelo Sr. F., uma segunda, a saber, a dos americanos, então náo resta nenhuma outra resposta: que a América seja muito fria ou muito nova para jamais produzir a derivação dos negros ou dos indianos amarelos, ou para ter já produzido no tấo curto tempo em que ela é povoada. A primeira afirmação, no que diz respeito ao clima quente dessa parte do mundo, está agora suficientemente refutada; e, no que tange à segunda, ou seja, de ainda que se tivesse a paciência de se esperar alguns milênios (pelo menos a propósito da cor da pele) aqui também por influência gradual do sol algum dia se encontrariam negros: primeiramente, seria preciso estar certo de que o sol e o ar podem fazer semelhante enxerto, apenas para se defender das objeçóes de um efeito meramente presumido, posto à distância e sempre a bel-prazer mais longe afastado, já que aquela é ainda muito passível de dúvida, quão pouco pode uma simples presunção arbitrária ser posta contra os fatos!

Umaimportanteconfirmaçãodaderivaçãodas diferençasconstantemente herdadas através das disposiçôes que se encontram originalmente juntas e conformes a fins em um tronco humano para a conservação da espécie é: que as raças daí desenvolvidas não se espalharam esporadicamente (em todas as partes do mundo, no mesmo clima, do mesmo modo), mas por $\operatorname{ciclos}^{17} \mathrm{em}$ porçóes unidas que são encontradas distribuídas no interior da linha de demarcação de uma terra onde cada uma das mesmas pôde se formar. Assim, a descendência pura dos Amarelos está contida no interior dos limites do Hindustão e, não muito distante daí, a Arábia, que em grande parte ocupa um clima semelhante, não contém nada disso; ambos, porém, não contêm negros, o quais somente são encontrados na África, entre Senegal e Cabo Negro (e assim por diante, no interior dessa parte do mundo); a América inteira, entretanto, não contém nem um nem outro, também nenhum caráter racial do Velho Mundo [177] (exceto os esquimós que, de acordo com as diferentes características tiradas tanto de sua feição quanto de seu próprio talento, parecem ser descendentes posteriores de uma raça da parte antiga do mundo). Cada uma dessas raças está, de algum modo, isolada e, já que no mesmo clima elas se diferenciam entre

${ }^{17}$ No original, Zykladisch. Certamente, trata-se de uma referência às Ilhas Cíclades: um arquipélago grego de formato circular em cujo centro se encontra a ilha sagrada de Delos. (N.T.) 
si e, na verdade, por um caráter inseparavelmente dependente da capacidade de procriação de cada uma das mesmas, assim elas tornam muito improvável a opinião sobre a origem do último, a partir do efeito do clima; ao contrário, confirmam a suposição de um parentesco universal de procriação pela unidade do tronco de origem, ao mesmo tempo, porém, a de uma causa da diferença que classifica as mesmas e que se situa nelas mesmas e não meramente no clima e que deve ter demandado muito tempo para fazer seu efeito adequado ao lugar de propagação, o que depois de, uma vez realizado, não permite mais possíveis novas derivaçóes por meio de transposiçóes, porque não pode ser tomado por nada mais que uma disposição original, posta no tronco em um certo número, limitada pelas principais diferenças de influência do ar e que se desenvolve gradativamente conforme a fins. Esse argumento parece ser prejudicado pela raça dos Papuas, dispersa pelas ilhas ao sul da Ásia e mais ao leste, pelo Oceano Pacífico, que eu e o cap. Forrester denominamos cafres (presumivelmente porque, em parte na cor da pele, em parte no cabelo e na barba que, contrariamente à característica dos negros, eles podem pentear num vistoso volume, ele encontrou motivo para não chamá-los de negros). Não obstante, além disso, a admirável dispersão que se encontra de outras raças ainda, a saber, dos haraforas e de certos homens mais próximos à linhagem indiana pura, vem a propósito, porque também fragiliza a prova do efeito do clima sobre sua qualidade hereditária, na medida em que esta sai, todavia, tão diferente sob um e mesmo clima. Por isso também com boas razões não se pode tomá-los por aborígenes, mas, provavelmente, por estrangeiros expulsos de seus lugares (os Papuas talvez de Madagascar), sabe-se lá por que motivo (talvez uma poderosa revoluçáo da terra que deve ter atuado do oeste para o leste). Com os habitantes da ilha de Freville, dos quais mencionei de memória (talvez incorretamente) o informe de Carteret, seja lá como quer que se tenha formado, se deverá buscar as provas do desenvolvimento das diferenças raciais no domicílio provável de sua linhagem no continente e não nas ilhas, que [178], como parece, foram povoadas só muito tempo depois de acabado o efeito da natureza.

Tudo para a defesa de meu conceito de dedução da multiplicidade hereditária das criaturas orgânicas de uma e mesma espécie natural (species naturalis, na medida em que elas podem estar em ligação por sua capacidade de procriação e ter provindo $^{18}$ de um único tronco) para a diferenciação da

\footnotetext{
${ }^{18}$ Pertencer a um e mesmo tronco não significa imediatamente ter sido produzido de um único par original; isso apenas quer dizer: as multiplicidades que agora são encontradas numa espécie animal não podem por isso ser consideradas como tantas diferenças originais. Agora, se o primeiro tronco humano
} 
espécie da escola (species artificialis, na medida em que elas ficam sob uma característica comum para a simples comparação) com o que, a primeira pertence à história da natureza, a segunda, à descrição da natureza. Agora, ainda algo mais sobre o sistema particular do Sr. F. e da origem do mesmo. Nisso ambos estamos de acordo: que tudo em uma ciência da natureza tem que ser explicado naturalmente, pois, do contrário, não pertenceria a essa ciência. Eu tenho seguido esse princípio tão cuidadosamente que, também um homem perspicaz (Sr. O. C. R. Büsching, na recensão de meu escrito acima mencionado), por conta de expressôes como propósitos, sabedoria e providência da natureza etc., me toma por um naturalista, todavia, com a ressalva, de um tipo próprio, porque, nas discussôes que concernem a meros conhecimentos da natureza e quáo longe esses alcançam (onde é inteiramente conveniente expressar-se teleologicamente), não acho aconselhável usar uma linguagem teológica; para assinalar muito cuidadosamente os limites para aquele tipo de conhecimento.

Precisamente o mesmo princípio, de que tudo na ciência da natureza deve ser explicado naturalmente, assinala ao mesmo tempo os limites da mesma. [179] De fato, chegou-se a seus limites extremos quando se faz uso do último entre todos os princípios explicativos que ainda pode ser confirmado pela experiência. Onde esses terminam e se tem que começar com forças da matéria que se inventa, segundo leis fabulosas e incapazes de quaisquer justificativas, aí já se está além da ciência da natureza, mesmo que sempre se nomeiem coisas naturais como causas, ao mesmo tempo, porém, atribuindo-lhes forças cuja existência por nada pode ser provada e, inclusive, cuja possibilidade dificilmente pode ser conciliada com a razão. Visto que o conceito de um ser organizado já comporta em si que ele seja uma matéria na qual tudo está relacionado entre si reciprocamente como fim e meio, e isso, inclusive, só pode ser pensado como um sistema das causas finais, por conseguinte, a possibilidade do mesmo, ao menos para a razão humana, permite apenas um modo de explicação teleológico, mas de maneira alguma um modo de explicação físico-mecânico: assim, na física, não se pode informar de onde, pois originalmente provém toda organização. A resposta

consistiu ainda de várias pessoas (de ambos os sexos), as quais porém eram todas similares, então eu posso tanto derivar precisamente os homens de hoje de um único par, como de vários do mesmo. O Sr. F. suspeitava que eu queria afirmar o último como um Faktum e na verdade por causa de uma autoridade; só que isso é apenas a ideia que inteira e naturalmente resulta da teoria. No que, porém, diz respeito à dificuldade de que o gênero humano, com seu início a partir de um par único, dificilmente estaria seguro por causa dos animais ferozes, isso não pode causar-lhe nenhum particular incômodo. Pois sua terra todocriadora podia ter criado os mesmos só depois dos homens. (K). 
a essa questão, caso, aliás, ela nos seja acessível, evidentemente ficaria fora da ciência da natureza, na metafísica. De minha parte, eu derivo toda organização do ser orgânico (por geração) e formas posteriores (desse tipo de coisas da natureza) segundo leis do desenvolvimento gradual de disposiçóes originais (as mesmas que frequentemente se deixam encontrar nas transplantaçôes das plantas) e que foram encontradas na organização de seu tronco. Como esse mesmo tronco se originou é um problema que fica além dos limites de toda física possível ao homem, no interior da qual eu acreditei ter que me manter.

Assim, nada receio de um tribunal da inquisição pelo sistema do Sr. F. (pois isso seria aqui exatamente como arrogar-se uma jurisdiçấo fora de seu domínio), também, em caso de necessidade, voto por um júri filosófico (p. 166) apenas de pesquisadores da natureza e, todavia, mal creio que sua sentença possa resultar-lhe favorável. "A terra em parto, (p. 80) que de seu tenro seio maternal fecundado pela lama do mar, deixou surgir animais e plantas, sem geração a partir de seus iguais, criou, nisso fundadas, as gerações locais de espécies orgânicas, então, a África e seus homens (os Negros), a Ásia e os seus (todos os demais) (p. 158), o parentesco de tudo daí derivado, em uma imperceptível gradação desde o homem à baleia (p. 77) e ainda mais para baixo (presumivelmente até os musgos e liquens, [180] não simplesmente num sistema de comparação, mas num sistema de procriação a partir de um tronco comum) em contínua cadeia natural ${ }^{19}$ de seres organizados" isso, de fato, não faria que o investigador da natureza perante tal recuasse estremecido, como que perante um monstro (p. 75), (porque é um jogo com o qual muitos uma vez se divertiram, do qual porém logo desistem, pois nada se consegue com isso), ele, contudo, seria afugentado daí, ao considerar que com isso desapercebidamente se extravia do solo fértil da investigaçáo da natureza para o deserto da metafísica. Além disso, conheço ainda um medo, não (p.75) precisamente afeminado, a saber, recuar de medo frente a tudo o que desprende a razão de seus primeiros princípios e lhe torna permitido divagar por quimeras ilimitadas. Talvez o Sr. F. tenha apenas desejado fazer um agrado a um hipermetafísico qualquer (pois há igualmente tais que não conhecem mesmo os conceitos elementares, que ainda se colocam a depreciálos e, todavia, intentam heroicamente conquistas) e dar matéria para aquelas fantasias, para depois se divertir com isso.

\footnotetext{
${ }^{19}$ Sobre essa ideia, popularizada principalmente por Bonnet, merece ser lida a Memória do Sr. Prof. Blumenbach (Manual de história natural, 1779, Prefácio, \$7). Esse homem sagaz atribui também o impulso de formação, pelo qual ele levou muita luz para a doutrina da geração, não à matéria inorgânica, mas apenas aos membros do ser organizado. (K).
} 
A verdadeira metafísica conhece os limites da razão humana e, entre outros, esse é seu defeito hereditário que ela jamais pode renegar: que ela simplesmente não pode e não deve forjar forças fundamentais a priori (porque então ela maquinaria conceitos meramente vazios), mas nada mais pode fazer do que reconduzir ao menor número possível aqueles que a experiência the ensina (na medida em que apenas segundo a aparência são diferentes, mas no fundo são idênticos) e procurar no mundo a devida força fundamental, quando se trata da física, contudo, caso necessário, quando porém se trata da metafísica (isto é, de indicar o que não é mais dependente) procurá-la fora do mundo. Mas de uma força fundamental (já que nós apenas a conhecemos pela relação de uma causa a um efeito) nós não podemos dar nenhum outro conceito nem descobrir para isso outra denominação do que aquela tomada do efeito e que expressa exatamente apenas essa relaçáo ${ }^{20}$. [181]. Ora, o conceito de um ser organizado é este: que ele seja um ser material possível apenas mediante relação recíproca, como fim e meio de tudo aquilo que nele está contido (como também todo anatomista, enquanto fisiólogo, realmente parte desse conceito). Uma força fundamental pela qual se produziria uma organização deve, pois, ser pensada como uma causa que atua segundo fins e, na verdade, de tal modo que esses fins devam ser postos como fundamento da possibilidade do efeito. Entretanto, nós conhecemos semelhantes forças, segundo seu fundamento de determinação, apenas pela experiência em nós mesmos, isto é, em nosso entendimento e vontade, como uma causa da possibilidade de certos produtos dispostos inteiramente segundo fins, a saber, as obras de arte. Entendimento e vontade são forças fundamentais em nós, das quais a última, na medida em que é determinada pela primeira, é uma faculdade de produzir algo conforme a uma ideia que é chamada fim. Nós não devemos, porém, conceber nenhuma

\footnotetext{
${ }^{20}$ Por ex., no homem a imaginação é um efeito que nós não reconhecemos como igual a outros efeitos do ânimo. A força que [181] diz respeito a isso só pode então ser chamada de força da imaginação (como força fundamental). Do mesmo modo, sob o título de forças motrizes, força de repulsão e atração são forças fundamentais. Para a unidade da substância, vários acreditaram ter que admitir uma única força fundamental e até pensaram conhecê-la ao qualificá-la pelo título comum de diversas forças fundamentais, por ex. a única força fundamental da alma seria a força de representaçáo do mundo; como se eu dissesse: a única força fundamental da matéria é a força motriz, pois repulsão e atração estáo ambas sob o conceito comum de movimento. Deseja-se, porém, saber se elas podem ser deduzidas dessa, o que é impossível. Pois os conceitos mais baixos jamais podem ser deduzidos dos superiores, segundo o que eles têm de diferente; e no que tange à unidade da substância, a qual parece que já comporta em seu conceito a unidade da força fundamental, entâo esse equívoco repousa sobre uma definiçấo incorreta de força. De fato, essa não é o que contém o fundamento da realidade dos acidentes (isso é a substância), mas é apenas a relação da substância aos acidentes, na medida em que ela contém o fundamento de sua realidade. À substância, porém, podem muito bem ser atribuídas diversas relaçóes (sem prejuízo de sua unidade). (K).
} 
nova força fundamental independentemente de toda experiência, isso seria o mesmo do que aquilo que atua em um ser de modo conforme a fins sem, contudo, ter o fundamento de determinação em uma ideia. Assim, o conceito da capacidade de um ser de, por si mesmo, atuar de modo conforme a fins, porém, sem fim e intenção que nele ou em sua causa repousasse - como uma força fundamental particular da qual a experiência não dá nenhum exemplo seria complemente fictício e vazio, isto é, sem a menor garantia [182] de que, em geral, the pudesse corresponder qualquer objeto. Dessa maneira, quer a causa do ser organizado seja encontrada no mundo quer fora do mundo, ou nós temos que renunciar a toda determinação de sua causa ou pensarmos para isso um ser inteligente; não como se nós compreendêssemos (como o acreditava o saudoso Mendelssohn, entre outros) que tal efeito fosse impossivel a partir de outra causa, mas, porque nós, para colocarmos como fundamento uma outra causa com exclusão das causas finais, deveríamos imaginar uma força fundamental para a qual a razáo não tem absolutamente nenhuma autorização, porque entâo não se lhe arrebataria nenhum esforço para explicar tudo o que ela quer e como ela quer.

E agora, a soma extraída de tudo isso. Os fins têm uma relação direta com a razão, seja ela estranha, seja a nossa própria. Contudo, para situá-los também em uma razão estranha, nós temos que colocar a nossa própria como fundamento, pelo menos como um análogo da mesma; pois sem isso eles absolutamente não poderiam ser representados. Ora, os fins são ou fins da natureza ou os fins da liberdade. Que devam existir fins na natureza, nenhum homem pode compreender a priori, ao contrário, ele pode muito bem compreender a priori que aí deva existir uma vinculação de causas e efeitos. Por conseguinte, o uso do princípio teleológico em relação à natureza é sempre empiricamente condicionado. Precisamente assim seria condicionado com os fins da liberdade, se os objetos do querer tivessem que ser previamente dados a esta através da natureza (em necessidades e inclinaçóes) enquanto fundamentos de determinaçáo para, meramente pela comparação das mesmas entre si e com sua soma, determinar por meio da razão aquilo que nós nos erigimos como fins. Só que a Crítica da razão prática mostra que há princípios práticos puros, pelos quais a razão é determinada a priori e que, portanto, indicam à mesma o fim a priori. Se, pois, o uso do princípio teleológico nas explicaçôes da natureza, 
visto ele ser limitado às condiçôes empíricas, jamais pode, completamente e para todos os fins, indicar determinada e suficientemente a origem da ligação conforme a fins; logo, ao contrário, é preciso esperar isso de uma doutrina pura do fim (que não pode ser outra senão aquela da liberdade), cujo princípio contém a priori a relação de uma razão em geral à totalidade de todos os fins e só pode ser prática. Não obstante, visto que uma teleologia prática [183], isto é, uma moral, é determinada a tornar seus fins reais no mundo, ela não pode descurar daquela possibilidade no mesmo, tanto no que diz respeito às causas finais nele dadas, como também no que concerne à adequação da causa suprema do mundo à totalidade de todos os fins como efeito, por conseguinte, tanto de uma teleologia natural, como também da possibilidade de uma natureza em geral, isto é, a filosofia transcendental, para assegurar realidade objetiva à doutrina prática pura do fim, no intuito da possibilidade do objeto na execução, a saber, aquela do fim que prescreve realizar no mundo.

Agora, ao considerar ambas, o autor das Cartas sobre a filosofia kantiana mostrou de maneira exemplar seu talento, sagacidade e modo de pensar digno de renome, ao empregar aquela de modo proveitoso para fins necessariamente universais; e conquanto seja demasiada exigência ao esmerado editor da presente revista, o que parece ofender a discrição, eu não pude, todavia, faltar em pedir-lhe permissão para poder inserir em sua revista meu reconhecimento do mérito do autor anônimo, e até pouco tempo por mim desconhecido, daquelas Cartas, pela causa comum de uma razão, tanto especulativa como prática, conduzida por princípios sólidos, na medida em que eu tenho me esforçado por fazer uma contribuição para isso. $\mathrm{O}$ talento de uma apresentação elucidativa e, inclusive, elegante de doutrinas áridas e abstratas sem a perda de sua profundidade é táo escasso (ao menos modesto, para um velho) e igualmente tão proveitosa, não quero dizer meramente por recomendação, mas mesmo pela clareza do exame, da inteligibilidade e do convencimento aí vinculado, que me julgo obrigado a agradecer publicamente àquele homem que de tal maneira completou meus trabalhos, aos quais não pude propiciar essa facilitação.

Nesta ocasião, quero ainda apenas aludir sumariamente à censura de supostas contradiçóes descobertas numa obra de considerável envergadura, antes que se a tenha compreendido inteiramente bem. Elas desaparecem todas por si mesmas, se as consideramos em ligação com o resto. $\mathrm{Na}$ Leipz. gel. Zeitung, 1787, n. 94, aquilo que está na Crítica etc., edição de 1787, na Introdução p. 3, linha 7, é apontado como em franca contradiçáo com o que 
se encontra logo depois, p. 5, linhas 1 e 2; pois, no primeiro lugar, eu disse: dos conhecimentos a priori chamam-se puros aqueles aos quais absolutamente [184] nada de empírico é acrescentado e, como exemplo do contrário, mencionei a proposição: toda alteração tem uma causa. Em compensação, na p. 5, mencionei precisamente essa proposiçáa como exemplo de um conhecimento puro a priori, isto é, de um tal que em nada é dependente do empírico; duas significaçóes da palavra puro, das quais porém em toda obra eu tenho a ver somente com a última. Decerto, eu poderia ter evitado o mal-entendido através de um exemplo do primeiro tipo de proposições: todo contingente tem uma causa. Pois aqui absolutamente nada de empírico é acrescentado. Mas quem pensa em todos os motivos para mal-entendidos? - Precisamente isso me ocorreu com uma nota do prefácio aos Princípios metafísicos da ciência da natureza, p. XVI-XVII, já que eu, na verdade, dava por importante a dedução das categorias, mas não por extremamente necessária, embora, por fim, diligentemente o afirmasse na Crítica. Vê-se facilmente, porém, que lá elas foram tomadas em consideração apenas com um intuito negativo, isto é, para provar que somente por meio delas (sem intuição sensível) absolutamente nenhum conhecimento das coisas se realiza, o que já fica claro ainda que apenas se leve em conta a exposição das categorias (meramente como funçôes lógicas aplicadas a objetos em geral). Destarte, porque nós fazemos um uso delas, na medida em que realmente pertencem ao conhecimento do objeto ( $\mathrm{da}$ experiência), logo foi preciso ser particularmente provada a possibilidade de uma validade objetiva de tais conceitos a priori em relação ao empírico, com o que elas não seriam julgadas como desprovidas de significação ou também como originadas empiricamente; e este foi o intuito positivo, em vista do qual a dedução é, sem dúvida, imprescindivelmente necessária.

Eu soube exatamente agora que o autor das Cartas acima citadas, o Sr. Conselheiro Reinhold, há pouco tempo é professor de Filosofia em Jena; um acréscimo que só pode ser muito vantajoso para essa renomada universidade.

I. Kant 